\title{
Molluscicidal activity of Punica granatum bark and Canna indica root
}

S.M. Tripathi and D.K. Singh

\author{
Department of Zoology, DDU Gorakhpur University, \\ Gorakhpur, India
}

\section{Correspondence \\ D.K. Singh \\ Malacology Laboratory \\ Department of Zoology DDU Gorakhpur University Gorakhpur-273 009, U.P. India}

Received December 7, 1999 Accepted June 21, 2000

\section{Abstract}

The molluscicidal activity of Punica granatum Linn. (Punicaceae) and Canna indica Linn. (Cannaceae) against the snail Lymnaea acuminata was studied. The molluscicidal activity of $P$. granatum bark and $C$. indica root was found to be both time and dose dependent. The toxicity of $P$. granatum bark was more pronounced than that of $C$. indica. The $24 \mathrm{~h} \mathrm{LC}_{50}$ of the column-purified root of $C$. indica was $6.54 \mathrm{mg} / \mathrm{l}$ whereas that of the column-purified bark of $P$. granatum was $4.39 \mathrm{mg} / \mathrm{l}$. The ethanol extract of $P$. granatum $\left(24 \mathrm{~h} \mathrm{LC}_{50}: 22.42\right.$ $\mathrm{mg} / \mathrm{l})$ was more effective than the ethanol extract of $C$. indica $(24 \mathrm{~h}$ $\left.\mathrm{LC}_{50}: 55.65 \mathrm{mg} / \mathrm{l}\right)$ in killing the test animals. $P$. granatum and $C$. indica may be used as potent molluscicides since the concentrations used to kill the snails were not toxic for the fish Colisa fasciatus, which shares the same habitat with the snail L. acuminata.
Key words

- Punica granatum

- Canna indica

- Plant molluscicide

- Lymnaea acuminata
The causative agents of endemic fascioliasis in the cattle population of eastern Uttar Pradesh are Fasciola hepatica and F. gigantica. These flukes are transmitted by the intermediate host snails Lymnaea acuminata and Indoplanorbis exustus. Use of molluscicides to eradicate the snail vector is considered the method of choice to eliminate fascioliasis $(1,2)$. Synthetic organic molluscicides have been widely used for the effective control of harmful snails (3). Today, it has been realized that these molluscicides are toxic to non-target animals and have a longterm detrimental effect on the aquatic environment $(2,4)$. Molluscicides of plant origin have become the focus of attention since they are less expensive and less hazardous to the environment than their synthetic counterparts (2). A large number of plant products which possess molluscicidal activity have been identified $(1,2,5)$. In the present study we evaluated in the laboratory the molluscicidal activity of different parts of Punica granatum Linn. (Punicaceae) and Canna indica Linn. (Cannaceae) against Lymnaea acuminata snails.

Bark of Punica granatum and root of Canna indica were collected locally. Specimens were identified by the staff of the herbarium of the Botany Department, DDU Gorakhpur University, Gorakhpur, where samples (Nos. 2125 and 2438) have been deposited. Different preparations were obtained from the bark of $P$. granatum and root of $C$. indica for the toxicity study. Pieces of $P$. granatum bark and root of $C$. indica were taken from the plant and kept in the incubator at $45^{\circ} \mathrm{C}$ for $48 \mathrm{~h}$. Dried pieces of these parts were pulverized with a grinder and the crude powder thus obtained was used for the toxicity experiment.

Five grams of $P$. granatum bark and $C$. 
indica root powder were extracted with 100 $\mathrm{ml}$ each of $95 \%$ ethanol, $99 \%$ methanol, $98 \%$ ether and $99.7 \%$ chloroform at room temperature for $12 \mathrm{~h}$. The solvents were removed under vacuum and the remaining dried parts $(P$. granatum ethanol $0.21 \mathrm{~g}$, methanol $0.24 \mathrm{~g}$, ether $0.06 \mathrm{~g}$, and chloroform $0.04 \mathrm{~g}$ and $C$. indica ethanol $0.05 \mathrm{~g}$, methanol $0.04 \mathrm{~g}$, ether $0.04 \mathrm{~g}$, and chloroform $0.03 \mathrm{~g}$ ) were used for the determination of molluscicidal activity.

One hundred milliliters of the ethanol extract fraction of both $P$. granatum bark and $C$. indica root were subjected to silica gel (60-120 mesh, Qualigens Glass, Precious Electrochemindus Private Limited, Bombay, India) chromatography through a $5 \times 45 \mathrm{~cm}$ column. Five-milliliter fractions eluted with ethyl alcohol (95\%) were collected. Ethyl alcohol was evaporated under vacuum and the remaining solids were used for the determination of molluscicidal activity.

Adult Lymnaea acuminata $(2.25 \pm 0.20$ $\mathrm{cm}$ in length) snails were collected locally and used as experimental animals. The animals were allowed to acclimatize to laboratory conditions for $72 \mathrm{~h}$. Toxicity experiments were performed by the method of Singh and Agarwal (6). Ten experimental animals were kept in a glass aquarium containing 3 liters of dechlorinated tap water. Snails were exposed to different concentrations of the preparations of $P$. granatum and $C$. indica and toxicity was observed for 24 , 48, 72 and $96 \mathrm{~h}$. Six aquaria were set-up for each concentration. Control animals were kept in an equal volume of dechlorinated water under similar conditions but without treatment. The dissolved oxygen in treated and control water was $6.5-7.2 \mathrm{mg} / \mathrm{l}$. The toxicity of these preparations was also tested on Colisa fasciatus fish.

Mortality was recorded every $24 \mathrm{~h}$ up to $96 \mathrm{~h}$ and dead animals were removed immediately so that other test animals would not be contaminated. Snail mortality was established by the contraction of the body within the shell; no response to a needle probe was taken as evidence of death. LC values, upper and lower confidence limits and slope values were calculated using the POLO computer software of Russell et al. (7). The regression coefficient between exposure time and different values of $\mathrm{LC}_{50}$ was determined (8).

The toxicity of the bark powder of $P$. granatum and of the root powder of $C$. indica and their organic solvent-extracted fractions against $L$. acuminata was time and dose dependent. Twenty-four-hour toxicity of $P$. granatum bark powder $\left(\mathrm{LC}_{50}-138.08\right.$ $\mathrm{mg} / \mathrm{l}$ ) against $L$. acuminata was higher than that of $C$. indica root powder $(773.58 \mathrm{mg} / \mathrm{l})$ (Tables 1 and 2). Ninety-six-hour $\mathrm{LC}_{50}$ of $P$. granatum bark powder and $C$. indica root powder against $L$. acuminata was $62.62 \mathrm{mg} / \mathrm{l}$ and $359.02 \mathrm{mg} / \mathrm{l}$, respectively (Tables 1 and 2).

Among the organic solvent-extracted fractions, the ethanol extract of bark was the most toxic. The 24-h $\mathrm{LC}_{50}$ of ethanol extracts of $P$. granatum bark and $C$. indica root against $L$. acuminata was $22.42 \mathrm{mg} / \mathrm{l}$ and $55.65 \mathrm{mg} / \mathrm{l}$, respectively (Tables 1 and 2). The column-purified fractions of both plants were highly toxic. The $24-\mathrm{h} \mathrm{LC}_{50}$ of the purified fraction of $P$. granatum bark was $4.39 \mathrm{mg} / \mathrm{l}$, whereas the $24-\mathrm{h} \mathrm{LC}_{50}$ of the purified fraction of $C$. indica root was 6.54 $\mathrm{mg} / \mathrm{l}$. At 96-h exposure the toxicity of the purified fractions was in the range of 0.94 to $1.84 \mathrm{mg} / 1$ (Tables 1 and 2). No mortality was observed in $C$. fasciatus fish exposed to the same concentrations as used in treatments against the snail L. acuminata.

The slopes were steep and the separate estimates of LC based on each of the six replicates were found to be within the $95 \%$ confidence limits of $\mathrm{LC}_{50}$. The t-ratio was greater than 1.96 and the heterogeneity factor less than 1.0. The g value was less than 0.5 at all probability levels (Tables 1 and 2).

It was evident from the above results that $P$. granatum (pomegranate) bark and $C$. in- 
dica root are potential sources of botanical molluscicides. Their toxic effects are time as well as dose dependent. The toxicity study revealed that the toxic components of $P$. granatum bark and $C$. indica root are water soluble. Punica granatum plants have been used for different therapeutic treatments as antidiarrhea, antiviral, antibacterial and antidiabetic agents (9-17). The dried bark of root and stem has long been used for the tapeworm treatment $(18,19)$. The bark and stem of $P$. granatum contain a number of alkaloids belonging to the pyridine group, namely pelletierine, pseudopelletierine, iso-pelletierine and methyl iso-pelletierine $(18,19)$. Among them, iso-pelletierine is the most potent taenicide $(18,19)$. Hukkeri et al. (18) reported that the aqueous extract of $P$. granatum fruit rind was more active against tapeworms than against earthworms and roundworms. It has been reported that iso-pelletierine causes muscular weakness followed by paralysis and death in treated animals. Production of an insecticidal preparation from $P$. granatum bark including the alkaloids and their tannates has been patented in

Table 1 - Toxicity $\left(\mathrm{LC}_{50}\right)$ of extracts of Canna indica root against the snail Lymnaea acuminata.

\begin{tabular}{|c|c|c|c|c|c|}
\hline \multirow{2}{*}{$\begin{array}{l}\text { Exposure } \\
\text { time }\end{array}$} & \multirow[t]{2}{*}{ Root extracts } & \multirow{2}{*}{$\begin{array}{l}\text { Lethal concentration } \\
\qquad \mathrm{LC}_{50}(\mathrm{w} / \mathrm{v}) \\
(\mathrm{mg} / \mathrm{l})\end{array}$} & \multicolumn{2}{|c|}{ 95\% Confidence limits } & \multirow[t]{2}{*}{ Slope value } \\
\hline & & & LCL (mg/l) & UCL (mg/l) & \\
\hline \multirow[t]{6}{*}{$24 \mathrm{~h}$} & Root powder & 773.58 & 649.60 & 1123.09 & $3.31 \pm 0.71$ \\
\hline & Methanol extract & 75.57 & 58.25 & 133.32 & $1.90 \pm 0.43$ \\
\hline & Ethanol extract & 55.65 & 42.29 & 95.60 & $1.94 \pm 0.39$ \\
\hline & Chloroform extract & 101.82 & 73.29 & 231.29 & $1.99 \pm 0.48$ \\
\hline & Ether extract & 111.43 & 70.81 & 629.85 & $1.36 \pm 0.43$ \\
\hline & Column purified & 6.54 & 5.67 & 7.87 & $2.65 \pm 0.49$ \\
\hline \multirow[t]{6}{*}{$48 \mathrm{~h}$} & Root powder & 579.73 & 509.67 & 719.47 & $3.10 \pm 0.64$ \\
\hline & Methanol extract & 48.23 & 38.90 & 66.92 & $1.74 \pm 0.04$ \\
\hline & Ethanol extract & 36.06 & 28.26 & 53.97 & $1.60 \pm 0.34$ \\
\hline & Chloroform extract & 71.27 & 54.60 & 130.56 & $1.73 \pm 0.42$ \\
\hline & Ether extract & 60.65 & 46.33 & 113.07 & $1.48 \pm 0.40$ \\
\hline & Column purified & 5.04 & 4.35 & 5.72 & $3.05 \pm 0.49$ \\
\hline \multirow[t]{6}{*}{$72 \mathrm{~h}$} & Root powder & 463.90 & 408.94 & 530.60 & $3.16 \pm 0.63$ \\
\hline & Methanol extract & 33.25 & 27.53 & 39.01 & $2.41 \pm 0.41$ \\
\hline & Ethanol extract & 23.47 & 18.04 & 30.49 & $1.57 \pm 0.33$ \\
\hline & Chloroform extract & 47.17 & 38.34 & 63.65 & $1.81 \pm 0.40$ \\
\hline & Ether extract & 33.76 & 25.15 & 42.47 & $1.67 \pm 0.40$ \\
\hline & Column purified & 4.07 & 3.07 & 5.80 & $1.35 \pm 0.27$ \\
\hline \multirow[t]{6}{*}{$96 \mathrm{~h}$} & Root powder & 359.02 & 304.84 & 400.26 & $3.71 \pm 0.67$ \\
\hline & Methanol extract & 23.46 & 17.73 & 27.95 & $2.52 \pm 0.44$ \\
\hline & Ethanol extract & 15.47 & 11.69 & 18.81 & $2.07 \pm 0.35$ \\
\hline & Chloroform extract & 29.90 & 23.10 & 35.90 & $2.08 \pm 0.41$ \\
\hline & Ether extract & 23.12 & 16.63 & 28.05 & $2.27 \pm 0.43$ \\
\hline & Column purified & 1.84 & 1.27 & 2.37 & $1.63 \pm 0.27$ \\
\hline
\end{tabular}


Japan (19). It seems that the higher molluscicidal activities of the column-purified fractions of $P$. granatum against $L$. acuminata are due to the number of alkaloids present in them.

It is clear from the present results that $C$. indica root has sufficient molluscicidal activity. It has been previously reported that aqueous and ether extracts of the whole plant and methanol extracts of root and leaves have molluscicidal activity $(20,21)$. Mahran et al. $(22,23)$ and Motawe $(24)$ have reported the molluscicidal potency of petroleum ether extracts of different parts of $C$. indica against Biomphalaria alexandrina snails, with root extracts being more toxic than other extracts. These investigators isolated a bioactive molluscicidal compound called cannagenin. It seems that the molluscicidal activity of column-purified fractions of $C$. indica root against $L$. acuminata was also due to cannagenins.

The steep slope indicates that even a small increase in the concentrations causes

Table 2 - Toxicity $\left(\mathrm{LC}_{50}\right)$ of extracts of Punica granatum bark against the snail Lymnaea acuminata.

Batches of 10 snails were exposed to different concentrations of the extract. Mortality was determined every $24 \mathrm{~h}$. Each set of experiments was replicated six times. Concentrations given are the final concentrations (mg/ I) in the aquarium water. The t-ratio was $>1.96$, the heterogeneity factor $<1.0$, and the $g$ value $<0.5$ at all probability levels. $\mathrm{LCL}$, Lower confidence limit; $\mathrm{UCL}$, upper confidence limit. The slope value is reported as mean \pm SEM. Significant negative regression $(P<0.05)$ was observed between exposure time and $L C_{50}$ of treatments. Testing significance of the regression coefficient - bark powder, $26.60^{+}$; methanol extract, $8.75^{+}$; ethanol extract, $4.27^{++}$; chloroform extract, $12.5^{++}$; ether extract, $7.03^{+}$; column purified, $7.70^{++}$. ${ }^{+}$Linear regression between $\mathrm{x}$ and $\mathrm{y} ;{ }^{++}$nonlinear regression between $\log \mathrm{x}$ and $\log \mathrm{y}$.

\begin{tabular}{|c|c|c|c|c|c|}
\hline \multirow{2}{*}{$\begin{array}{l}\text { Exposure } \\
\text { time }\end{array}$} & \multirow[t]{2}{*}{ Root extracts } & \multirow{2}{*}{$\begin{array}{l}\text { Lethal concentration } \\
\qquad \mathrm{LC}_{50}(\mathrm{w} / \mathrm{v}) \\
(\mathrm{mg} / \mathrm{l})\end{array}$} & \multicolumn{2}{|c|}{ 95\% Confidence limits } & \multirow[t]{2}{*}{ Slope value } \\
\hline & & & $\mathrm{LCL}(\mathrm{mg} / \mathrm{l})$ & UCL (mg/l) & \\
\hline \multirow[t]{6}{*}{$24 \mathrm{~h}$} & Bark powder & 138.08 & 115.54 & 202.72 & $3.35 \pm 0.72$ \\
\hline & Methanol extract & 29.52 & 23.99 & 48.55 & $2.67 \pm 0.64$ \\
\hline & Ethanol extract & 22.42 & 17.81 & 35.18 & $2.20 \pm 0.45$ \\
\hline & Chloroform extract & 30.77 & 21.93 & 72.80 & $1.93 \pm 0.47$ \\
\hline & Ether extract & 31.98 & 22.69 & 77.40 & $2.01 \pm 0.49$ \\
\hline & Column purified & 4.39 & 3.54 & 5.72 & $1.80 \pm 0.29$ \\
\hline \multirow[t]{6}{*}{$48 \mathrm{~h}$} & Bark powder & 114.32 & 97.66 & 156.93 & $2.84 \pm 0.63$ \\
\hline & Methanol extract & 21.46 & 18.61 & 27.23 & $2.76 \pm 0.59$ \\
\hline & Ethanol extract & 11.03 & 9.41 & 12.89 & $2.59 \pm 0.39$ \\
\hline & Chloroform extract & 18.62 & 14.75 & 28.96 & $1.81 \pm 0.40$ \\
\hline & Ether extract & 20.23 & 15.66 & 34.42 & $1.73 \pm 0.40$ \\
\hline & Column purified & 2.58 & 1.96 & 3.24 & $1.69 \pm 0.27$ \\
\hline \multirow[t]{6}{*}{$72 \mathrm{~h}$} & Bark powder & 84.79 & 73.28 & 101.64 & $2.64 \pm 0.60$ \\
\hline & Methanol extract & 16.05 & 14.10 & 18.10 & $3.27 \pm 0.58$ \\
\hline & Ethanol extract & 7.60 & 5.99 & 8.99 & $2.44 \pm 0.39$ \\
\hline & Chloroform extract & 11.88 & 9.75 & 14.72 & $1.99 \pm 0.38$ \\
\hline & Ether extract & 12.08 & 9.83 & 15.19 & $1.90 \pm 0.38$ \\
\hline & Column purified & 1.53 & 1.26 & 1.94 & $2.00 \pm 0.35$ \\
\hline \multirow[t]{6}{*}{$96 \mathrm{~h}$} & Bark powder & 62.62 & 52.09 & 70.33 & $3.32 \pm 0.63$ \\
\hline & Methanol extract & 12.12 & 10.27 & 13.56 & $3.88 \pm 0.61$ \\
\hline & Ethanol extract & 8.47 & 6.87 & 9.94 & $2.46 \pm 0.39$ \\
\hline & Chloroform extract & 8.67 & 6.97 & 10.25 & $2.32 \pm 0.38$ \\
\hline & Ether extract & 7.63 & 5.90 & 9.12 & $2.28 \pm 0.38$ \\
\hline & Column purified & 0.94 & 0.79 & 1.08 & $2.87 \pm 0.41$ \\
\hline
\end{tabular}


higher snail mortality. Values of the t-ratio higher than 1.96 indicate that the regressions are significant. Values of the heterogeneity factor of less than 1.0 denote that in the replicate test of the random sample the concentration-response curves would fall within the $95 \%$ confidence limits and thus the model fits the data adequately. The index of significance of potency estimation, $g$ value, indicates that the value of the mean is within the limits at all probabilities $(90,95,99)$ since it is less than 0.5 .

On the basis of the present study, we conclude that $P$. granatum and $C$. indica may be used as potent molluscicides since the concentrations used to kill snails were not toxic for $C$. fasciatus fish. The mechanism by which these preparations cause snail death is not exactly known and will require further studies for elucidation.

\section{References}

1. Hostettmann K \& Lea PJ (1987). Biologically Active Natural Products. Oxford Science Publication, Oxford.

2. Singh A, Singh DK, Misra TN \& Agarwal RA (1996). Molluscicides of the plant origin. Biological Agriculture and Horticulture, 13: 205-252.

3. Agarwal RA \& Singh DK (1988). Harmful gastropods and their control. Acta Hydrochimica et Hydrobiologica, 16: 113-138.

4. US Congress (1976). House of representative committee on government operation of EPA's implementation of pesticides control act: hearings before subcommittee on Government operation of house of representative 94th congress session, February 11 and March 5, 1976. US Government Printing Office, 1-222.

5. Alard F, Geerts S \& Triest ETL (1991). Toxicite d' Ambrosia maritima L. Plant molluscicide, sur les organismes aquatiques non-cibles. Toxicon, 29: 745-750.

6. Singh DK \& Agarwal RA (1984). Correlation of the anticholinesterase and molluscicidal activity of the latex of Euphorbia royleana Bioss. on Lymnaea acuminata. J ournal of Natural Products, 47: 702-705.

7. Russell RM, Robertson JL \& Savin NE (1977). POLO: A new computer programme for probit analysis. Bulletin of the Entomological Society of America, 23: 209-213.

8. Sokal RR \& Rohlf FJ (1973). Introduction to Biostatistics. W.H. Freeman and Co., San Francisco, 271-273.

9. Zofar R \& Singh J (1990). Antidiabetic activity of Punica granatum Linn. Science and Culture, 56: 303-304.

10. Pillai NR (1992). Antidiarrhoeal activity of Punica granatum in experimental animals. International J ournal of Pharmacognosy, 30: 201-204.

11. Bala S \& Grover IS (1992). Antimutagenic effect of pomegranate (Punica granatum variety Anardana) fruit extract on direct acting and 59-dependent mutagens in Salmonella typhimurium. J ournal of Plant Science Research, 8: 14-16.

12. Naqvi SAH, Siddigi TO, Hamdard ME \& Hameed A (1992). Antiamoebic activity of rind and flowers of Punica granatum Linn. J ournal of Science of the Islamic Republic of Iran, 4: 1-3.

13. Pradhan KD, Thakur DK \& Sudhan NA (1992). Therapeutic efficacy of Punica granatum and Cucurbita maxima against clinical cases of nematodiasis in calves. Indian J oumal of Indigenous Medicines, 9: 53-55.

14. Cristina P \& Claudia A (1994). In vitro antibacterial activity of Argentine folk medicinal plants against Solminala typhi. J ournal of Ethnopharmacology, 44: 41-46.

15. J ie Z, Bin Gyan Z, Xuenjun Y, Youxin G \& J incun $S$ (1995). Antiviral activity of tannin from the pericarp of Punica granatum Linn. against genital herpes virus in vitro. Zhonghua Zhongliu Zazhi, 20: 556-558.

16. Navarro V, Villarreal ML, Rojas G \& Lozoya $X$ (1996). Antimicrobial evaluation of some plants used in Mexican traditional medicine for the treatment of infectious diseases. J ournal of Ethnopharmacology, 53: 143-147.
17. Alkofahi A, Batshoun R, Owais W \& Najib N (1997). Biological activity of some J ordanian medicinal plant extracts. Fitoterapia, 68: 163-168.

18. Hukkeri VI, Kalyani GA, Hatapaki BC \& Manvi FV (1993). In vitro anthelmintic activity of aqueous extracts of fruit rind of Punica granatum. Fitoterapia, 64: 69-70.

19. Anonymous (1995). The Wealth of India, Raw Materials. Vol. VIII. Publication and Information Directorate, CSIR, New Delhi, 317-324.

20. Kloos H \& McCullough FS (1982). Plant molluscicides. Planta Medica, 46: 195209.

21. Kloos H \& McCullough FS (1987). Plants with recognised molluscicidal activity. In: Mott KE (Editor), Plant Molluscicides. UNDP/World Bank/WHO, Geneva and J ohn Wiley \& Sons, Chichester, 45-108.

22. Mahran GH, Saleh M, Hossary El GH, Motawe HM \& Mohammad AM (1974). A contribution to the molluscicidal activity of Canna indica L. family Cannaceae as a method for control schistosoma. Egyptian J ournal of Bilharziasis, 1: 279-286.

23. Mahran GH, Saleh M, Hossary EI GH, Motawe HM \& Mohammad AM (1977). Isolation and identification of certain molluscicidal substances in Canna indica L. J oumal of African Medicinal Plants, 1 : 107-119.

24. Motawe HM (1994). Cannagenin: A new molluscicidal agent from Canna indica $L$. J ournal of Herbs, Spices and Medicinal Plants, 2: 3-10. 